\title{
Estimation of Population Density of the Common Vole in Poland: An Analysis of Owl Pellets
}

\author{
Krystyna CABOŃ-RACZYŃSKA \& Andrzej L. RUPRECHT
}

\begin{abstract}
Caboń-Raczyńska K. \& Ruprecht A. L., 1977: Estimation of population density of the common vole in Poland: an analysis of owl pellets. Acta theriol., 22, 25: 349-354 [With 1 Fig.].

On the basis of 804 samples of the barn owl and the tawny owl pellets from the whole area of Poland estimation was made of relative density of the common vole. Average population density of $M$. arvalis was worked out using the square networks of $2,500 \mathrm{~km}^{2}$ of the UTM system. Mean density values was graded as follows: $0-19 \%$ low; $20-39 \%$ medium; $40-59 \%$ high; over $60 \%$ very high. The western and south-western parts of Poland are distinguished by a high and very high density of the common vole population. In the remaining parts of Poland the high density value is reserved for some of territorial enclaves. Medium and low density of $M$. arvalis population is characteristic for the rest part of Poland. Similar results has been obtained by other authors using the questionnaire method.

[Mammals Res. Inst., Polish Acad. Sci., 17-230 Białowieża, Poland].
\end{abstract}

\section{INTRODUCTION}

Mass occurrences of the common vole, Microtus arvalis ( $\mathrm{P}$ a $11 \mathrm{as}$, 1779) were investigated both in western ( $\mathrm{Si} \mathrm{m} \mathrm{m} \mathrm{\&} \mathrm{Skurat} \mathrm{ow} \mathrm{i} \mathrm{c} \mathrm{z,}$ 1950) and south-eastern parts of Poland ( $\mathrm{M} \mathrm{i} \mathrm{g} \mathrm{u} \mathrm{l}$ a et al., 1970). Similar researches have been the object of our earlier work ( $\mathrm{Cab}$ on-R a c z yńska \& Ruprecht, 1970). They concerned evaluation of the population density of the common vole by means of analysis of owl pellets collected over a wide area of Poland. Corresponding assays of evaluation of $M$. arvalis were carried out also in France (S a in t-Gi rons \& Spitz, 1966) and in Hungary (Schmidt, 1971-72; Schmidt et al., 1973).

Importance of such investigations for agriculture as well as possession of owl pellets collected all over Poland enabled the authors to investigate the frequency of occurrence of $M$. arvalis in owl diets and to trace zones of its mass appearance in the country. Attempts were made to collate the relative density of the common vole with the classification of soils and prognosis of mass occurrences of this species (A d a m c z e w s kA ndrzejewska, 1974; B a ndomir et al., in preparation). 


\section{MATERIAL AND METHOD}

Seven hundred samples of owl pellets were investigated together with hundred four samples analysed already by others (C z a rnecki et al., 1955; C a is, 1963; Ruprecht, 1964 and 1971; Kulczycki, 1964). Unpublished data from M. Sc. thesis at the Poznan University were also taken into account.

Most of the pellets collected in years 1950-1976 belonged to the barn owl, Tyto alba (S c o poli, 1769), part, however to the tawny owl, Strix aluco (Lin$\mathrm{n}$ a e u s, 1758). A sample of pellets consisted of a single collection from one owl roost. The percentage of vole occurrence among other mammals was estimated for every sample collected. Only samples containing more than 30 individual Micromammalia were taken under consideration in our calculations. Population density of $M$. arvalis was worked out using the square networks of the UTM system. Mean percentage of density was calculated for a surface-unit equal to $2,500 \mathrm{~km}^{2}$ i.e. a square $50 \mathrm{~km}$ wide. Usually 1 to 55 samples fall to one surface unit. Mean density value of $M$. arvalis population was graded as follows: $0-19 \%$ low; $20-39 \%$ medium; $40-59 \%$ high; over $60 \%$ very high.

\section{RESULTS}

The western part of Poland, particularly Kotlina Sląska and Sudety Mts, Ziemia Lubuska, Nizina Wielkopolsko-Kujawska and the western part of Pojezierze Pomorskie are distinguished by a high density value of the vole population. In the remaining parts of Poland the high density value is reserved for territorial enclaves and occurred among others in Pojezierze Mazurskie (square $D E$ and $E E$ ) in Nizina Mazowiecko-Podlaska $(C D)$, Podlasie $(F D)$, in Beskid Sądecki Mts $(D V)$ and in the eastern part of the highlands $(F A)-$ Fig. 1 . Such high density is characteristic chiefly for highly fertile and fertile soils. Possible exception can be the high density value of vole population in the Beskid Sądecki Mts (DV) which has poor soils (S trzemski \& Witek, 1970).

Low population density of $M$. arvalis is characteristic for east Poland — especially for Wyżyna Lubelska and Podlasie, Pojezierze Suwalskie including. Similarly low density is observed in the region of Góry Swiętokrzyskie and the east part of Pojezierze Pomorskie (Fig. 1), which usually are distinguished by vast forests encompassing arable field enclaves (cf. Strzemski \& Witek, 1970).

Medium density is characteristic for the rest of Poland, i.e. one third of it which comprises, in general, wide lowlands, some uplands, both having various types of soils.

\section{DISCUSSION}

Knowledge of the population density of the common vole over the whole range of Poland has great economic importance considering per- 
iodical mass occurrences and damages wrought by this species. Therefore localization of particularly threatened fields, together with a suitable prophylactic local action should be the first step in opposing disaster (Si m m \& Skuratowicz, 1950).

Our method has, of course, a restricted practical use. It is best fitted for registration of threatened zones and areas exposed to mass occurrences of $M$. arvalis. It cannot, however, substitute for provisional defence

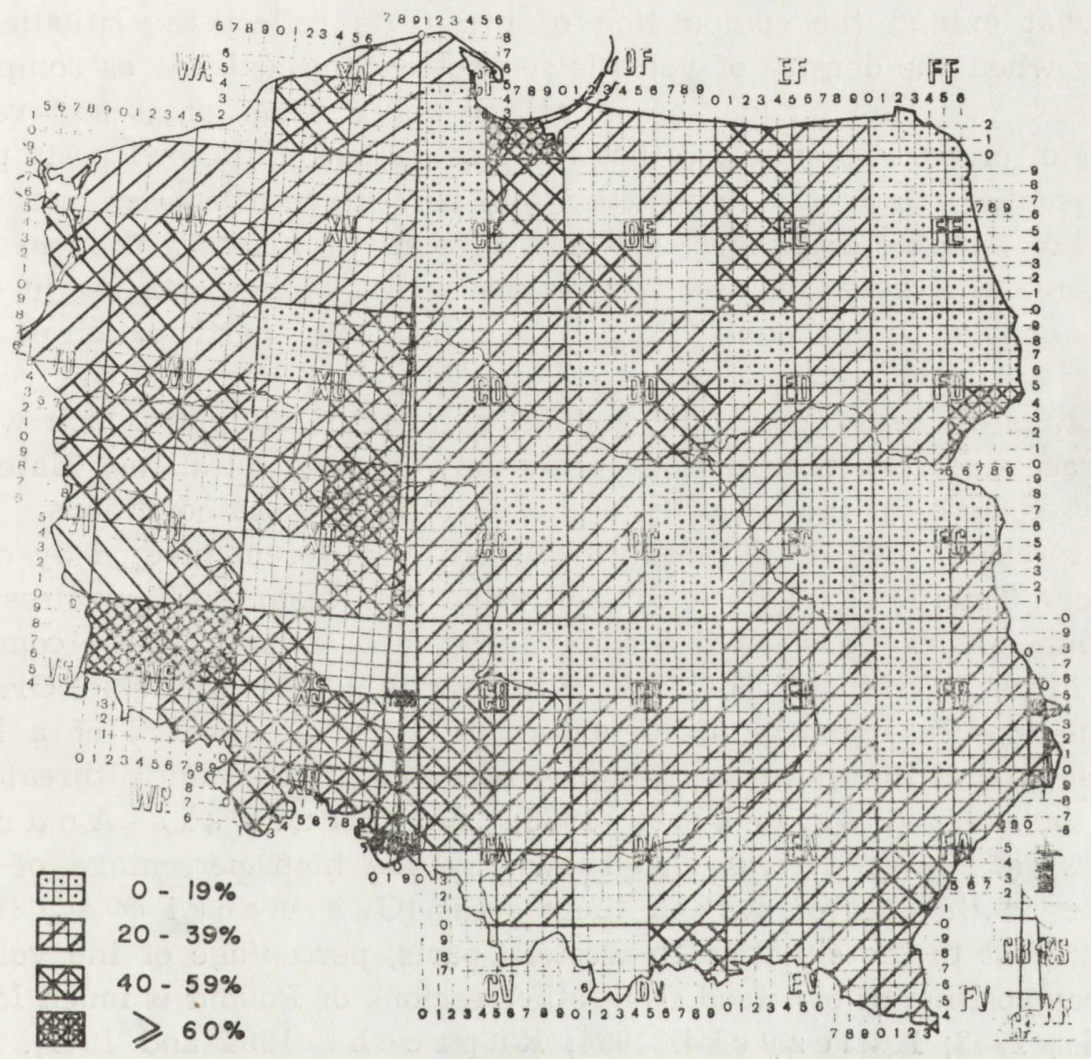

Fig. 1. Relative density of Microtus arvalis in Poland, as determined by average percentage of its remains in owl pellets.

actions based on current controls and registrations of mass appearances of the vole which is threatening the crops. The majority of samples of owl pellets consisted of single rich collections representing a deposit of food of many years standing. This kind of samples can be considered as the most appropriate for evaluation of the mean percentage of $M$. arvalis in the fauna of small mammals of the open country. However, 
the value of this method can be restricted if one takes samples only from one season or of one year standing. Such collections depict only extreme situations deducted from the amplitude of fluctuations of the number of basic types of mammals eaten by the owls. Therefore objective results were achieved only by combining the results of all samples found on one surface unit, a square of $50 \times 50 \mathrm{~km}$. Of course some limited areas containing enclaves of great population density of the vole need not give representative values of their density. It is not yet clear to what extend the composition of owl diets reflect the situation in years when the density of voles is restricted to greenlands as compared to years in which plagues of $M$. arvalis cover wider areas and varied types of crops. It seems also that the localization of the owl nests plays an essential role in the composition and percentage of species in a sample. For instance neighbourhood of wet meadows means a drop in field species and increase in insectivorous mammals, whereas nesting in open fields or near farms (small villages) favours greater participation of field and synanthropic species in the pellets. To gain really objective results it is thus necessary to handle a great number of samples which would embrace different time periods preferably of long durations. Materials analysed here, in the majority of cases fulfilled these conditions.

Our results coincide with data obtained by different method by other authors. Thus Mig ula et al. (1970) using data from questionnaires and personal observations noted a slight increase of density of the common vole in voivodeships of Kieleckie, Krakowskie and Rzeszowskie. Greater fluctuations in numbers of $M$. arvalis in these areas were of a local character, but the south-western part of Poland is constantly threatened by the vole (Romankow, 1973; Adamczewska-Andrzejewska, 1974). It was also shown by the high percentage of this species in the diet of owls in these areas ( $\mathrm{Cz}$ a rne c ki et al., 1955). In contrast to the situation in western parts, percentage of the vole in the composition of owl food from other regions of Poland is much lower (C a is, 1963; K ulczycki, 1964; Ruprecht, 1964 and 1971). This means that these regions are not threatened by a possibility of mass appearance of voles over larger areas. And this is reflected by a constantly low percentage of $M$. arvalis in samples collected few times a year from Lubelszczyzna (C a b oń-R a c z yńs k a \& R u p r e cht, 1970).

Our method permitted to fix regions of a relatively high population density of $M$. arvalis. The data in a considerable degree matched the results of few years investigations undertaken for whole Poland by the Institute of Ecology of the Polish Academy of Sciences (B a ndomir et al., in preparation). Mean values of density obtained by us for definite areas agree completely with the density values characteristic for these 
areas in years of mass occurrence (for instance 1972 and 1975). This concerns, first of all, the south-western provinces, as well as small local regions scattered over different parts of Poland.

It seemed reasonable to relate high degree of population density of the vole - therefore possibility of mass appearance - to the soil conditions, since maximum density of voles was ascertained by us in regions with highly fertile soils and poor in forests. On the contrary, on territories ecologically unfavourable as regards geographical configuration, soil and afforestation, mass appearances can occur only when farming continuity is disturbed (M g u la et al., 1970).

Data obtained by our method depict as close a picture of true population density of $M$. arvalis as gained either by a questionnaire method or by direct counts of the rodents. It seems therefore that this method can be applied to control the fluctuations of the number of common vole on terrains threatened by its mass occurrence.

\section{REFERENCES}

1. A d a mczewska-Andrzejewska K., 1974: Prognozowanie zmian zagęszczenia nornika polnego (Microtus arvalis Pall.) w oparciu o pogłębioną analizę populacji. Biuletyn Instytut Ochrony Roślin, 57: 393-400. Poznań.

2. Bandomir B., Leman M., Olech B. \& Tokarczyk G. (in prep.): Występowanie nornika polnego (Microtus arvalis Pall.) w Polsce na podstawie ankiety.

3. Ca is L., 1963: Badania nad składem pokarmu kilku gatunków sów. Zesz. Nauk. Uniw. A. Mickiewicza w Poznaniu, Biol., 4: 3-21.

4. Caboń-Raczyńska K. \& Ruprecht A. L., 1970: Distribution and relative density of Microtus arvalis ( $\mathrm{P}$ a 11 a s, 1779) in Poland as based on an analysis of owl pellets. EPPO Public. Ser. A. N0 58: 81-85.

5. Czarnecki Z., Gruszczyńska J. \& S moleńska E., 1955: Badania nad składem pokarmu płomykówki [Tyto alba guttata (C.L.Br.)] w latach 19501952 w województwie poznańskim. Pozn. Tow. Przyj. Nauk, Pr. Kom. Biol., 16, 3: $1-38$.

6. Kulczycki A., 1964: Badania nad składem pokarmu sów z Beskidu Niskiego. Acta zool. Cracov., 9, 9: 529-559.

7. Migula P., Grodziński W., Jasiński A. \& Musiałek B., 1970: Vole and mouse plagues in south-eastern Poland in the years 1945-1967. Acta theriol., 15, 16: 233-252.

8. Romankow A., 1973: Nasilenie liczebności nornika polnego (Microtus arvalis Pallas) w Polsce w roku 1972 oraz prognoza na rok 1973. Biuletyn Instytutu Ochrony Roślin, 55: 359-360.

9. Ruprecht A., 1964: Analiza składu pokarmu płomykówki Tyto alba guttata (C.L.Br.) z Aleksandrowa Kuj., Ciechocinka i Raciążka w latach 1960-1961. Zesz. Nauk. Uniw. M. Kopernika w Toruniu, Nauki Mat.-Przyr., zesz. 9, Biol., 7: $45-66$.

10. Ruprecht A. L., 1971: O składzie pokarmu płomykówki (Tyto alba guttata) z Nieszawy (woj. bydgoskie). Przyr. Pol. Zach., 9, 1-4: 72-78. 
11. Saint-Girons M. C. \& Spitz F., 1966: A propos de l'etude des Micromammifères par l'analyse des pelotes de Rapaces. Interet et limites de la methode. La Terre et la Vie, 1: 3-18.

12. S ch midt E., 1971-1972: Angaben über die relative Häufigkeit der Feldmaus (Microtus arvalis) in Ungarn, auf Grund von Gewöllenuntersuchungen der Waldohreule (Asio otus). Aquila, 78-79: 189-196.

13. Schmidt E., Somogyi P. \& Szentendrey G., 1973: Ein Versuch zur Feststellung der Populationsdichte einiger Kleinsaeuger in offenen Kulturgebieten auf Grund von Schleiereulengewoellen. Vertebr. Hung., 12: 79-91.

14. Si m m K. \& Skuratowicz W., 1950: Z badań nad masowym pojawem gryzoni polnych na ziemiach zachodnich w r. 1946/47. Badania Fizjograf. nad Pol. Zach., Pozn. Tow. Przyj. Nauk, Wydz. Mat.-Przyr., Komitet Fizjograficzny, nr 2, zesz. 2: 178-218.

15. Strzemski M. \& Witek T., 1970: Rolnicza przydatność gleb. [In: »Narodowy Atlas Polski«, Zakł. Nar. im. Ossolińskich], page: 66.

Accepted, March 12, 1977.

Krystyna CABOŃ-RACZYŃSKA \& Andrzej L. RUPRECHT

OCENA ZAGESZCZENIA POPULACJI NORNIKA ZWYCZAJNEGO W POLSCE: ANALIZA ZRZUTEK SOW

\section{Streszczenie}

Na podstawie 804 zbiorów zrzutek sów z terenu całej Polski obliczono względne zagęszczenie $M$. arvalis, przypadające na jednostkę powierzchni $2,500 \mathrm{~km}^{2}$. Przeciętne zagęszczenie nornika zwyczajnego przedstawiono na siatce UTM, przyjmując następującą skalę: $0-19 \%$ niskie; $20-39 \%$ średnie; $40-59 \%$ wysokie oraz powyżej $60 \%$ bardzo wysokie (Fig. 1). Stwierdzono, że wysokie i b. wysokie zagęszczenie tego szkodnika ma miejsce w południowo-zachodniej i zachodniej części Polski, znanych z masowych pojawów tego gatunku. Srednie i niskie zagęszczenie $M$. arvalis cechuje natomiast pozostały obszar kraju. Względne zagęszczenie $M$. arvalis w Polsce pokrywa się $\mathrm{w}$ znacznym stopniu $\mathrm{z}$ danymi $\mathrm{z}$ prognoz, uzyskanymi $\mathrm{za}$ pomocą ankiet. 